\title{
GLOBAL POLITICAL AND ECONOMIC GOVERNANCE
}

\author{
H. H. S. Viswanathan' \\ Mihir Swarup Sharma²
}

This paper provides an overview about the challenges of multipolarity and globalization, focusing on various institutions of global governance, and how BRICS are making efforts to overcome them, considering the interests of the grouping in each as well as what positive changes could and are being brought about with respect to each.

Keywords: multilateralism; globalization; BRICS; global governance.

\section{GOVERNANÇA POLÍTICA E ECONÔMICA GLOBAL}

Este artigo fornece uma visão geral sobre os desafios da multipolaridade e da globalização, focando diversas instituições de governança global, e sobre como Brasil, Rússia, Índia, China e África do Sul (BRICS) estão fazendo esforços para superá-los, considerando os interesses do bloco, bem como as mudanças positivas que podem e estão sendo introduzidas em relação a cada um deles.

Palavras-chave: multilateralismo; globalização; BRICS; governança global.

\section{GOBERNANZA POLÍTICA Y ECONÓMICA GLOBAL}

Este artículo oferece un panorama general en relación a los desafíos de la multipolaridad y de la globalización, con foco en diversas instituciones de gobernanza global y en los esfuerzos realizados por los países del BRICS para superarlos, tomando en consideración los intereses del bloque, asi como los cambios positivos que están y que podrian estar siendo introducidos en cada uno de ellos.

Palabras clave: multilateralismo; globalización; BRICS; gobernanza global.

JEL: F50.

Data de envio do artigo: 10/3/2020; Data de aceite: 24/3/2020.

\section{INTRODUCTION}

Over the past two decades, the world has seen the shift in economic power in favour of emerging economies and some developing countries. The apparent "retreat" of globalisation in recent years does not detract from the fact that this is

1. Distinguished fellow at the Observer Research Foundation (ORF) in New Delhi. He has been the Head of the Indian Delegation to many BTTC Meetings and BRICS Academic Forums. He has co-edited the book In Search of Stability, Security and Growth: BRICS and a new world order. Earlier, he was an Indian Diplomat and has served as India's envoy in many countries.

2. Senior fellow and head of the Economy and Growth Programme at Observer Research Foundation (ORF) in New Delhi. He was trained as an economist and political scientist in Delhi and Boston. He has edited and written columns for the opinion pages of The Indian Express and Business Standard, both based in New Delhi. His book Restart: the last chance for the Indian economy was published in 2015. He is also the India columnist for Bloomberg View. 
still a hyper-globalised and interdependent world. Such interdependence means that that global political and economic governance - or, more often, the lack of it - is a serious challenge to humanity's future.

Multiple challenges facing the human race are caused by factors beyond the control of any single sovereign state, and require global solutions. These issues terrorism, climate change, energy and food security, trade liberalisation, connectivity infrastructure, cyber security, migration - all cut across national boundaries. The high-speed transfer of goods, capital, pathogen and environmental externalities across national borders has made such boundaries irrelevant - except when it comes to framing solutions. Although no single nation can craft a comprehensive national approach to any one of these problems without taking into account the actions of the rest of the world, the question is whether the mechanisms of global governance are today capable of addressing these problems.

The BRICS' approach to global governance and its reform fits into a long historical tradition that finds itself at a point of inflection. Throughout history, societies and later Westphalian states found ways of laying down some acceptable ground rules of behaviour to all that could ensure the smooth conduct of interactions and engender co-operation. Unsurprisingly for realist scholars of international relations, these rules usually favoured the more powerful among the group. The simplest definition of global governance is "the management of transnational issues through voluntary international cooperation" (Altinay, 2010). The operative term here is "voluntary", which places sovereign choice at the heart of any association.

This paper provides an overview about the challenges of multipolarity, focusing on various institutions of global governance as they pertain to the BRICS project, and how BRICS are making efforts to overcome them, considering the interests of the grouping in each as well as what positive changes could and are being brought about with respect to each. These institutions are, of course, in both the political and the economic spheres.

\section{HOW IS THE GLOBAL ORDER CHANGING?}

There are three fundamental elements to global governance: values, norms and rules. These should inform the kinds of institutions that will serve as the mechanisms by which global governance is realised. A fair and equitable system of governance should not only address all the three elements but also have them in the correct sequence. History shows us that powerful nations have imposed rules first and then justified them subsequently by purely subjective values.

Any set of rules associated with global governance is closely linked to the global order that gave them birth. The underwriters of the architecture of global governance are also those who dominate the global order. However, as Dmitri 
Trenin (2015) points out, "life expectancy of world orders varies, but like humans, they are mortal". These orders in the past have changed because of wars and violent events. In a globalized and inter-connected world, there is the hope that a change of guard will instead be conducted in a peaceful and harmonious manner.

There is no doubt that the time has arrived for a change in global order and global governance. According to Ian Bremmer (2015), "the world has entered a phase of geopolitical creative destruction”. Both the post Second World War and post-Cold War orders have become outdated and obsolete.

If there has to be a significant change in global governance structures, what would this change signify? More concretely, who should take the lead in bringing about the change? The post-war order depended upon the mutual antagonism of two superpowers; after the collapse of the Soviet Union, the global order was essentially underwritten by the United States alone. It continued to use the structures designed by the victors of the Second World War as the mechanism by which global governance was undertaken.

It turned out, these were as suited to a unipolar world as they were to a bipolar one. It now turns out that they are struggling to deal with a multipolar world as they were not with either unipolarity or bipolarity. Multilateralism under unipolarity was not difficult to manage. Pax Americana had significant benefits, including the colossal expansion of world trade following the creation of the World Trade Organization.

However, for numerous reasons, this form of global organisation has been outgrown. The United States itself has threatened to turn inwards in a manner that it has not for over 70 years. Meanwhile strong economic growth in what was once the periphery of the global economy and now bids fair to become its core means that the world's institutions no longer accurately reflect the centre of economic power.

Has there been a commensurate shift in political power? The answer, unfortunately, is in the negative. While the so-called status quo powers argue that there should be greater burden sharing by the emerging economies in managing global problems, they are reluctant to have a matching amount leadership sharing. Why should emerging and developing countries take on more burden if it is to perpetuate the existing order and system of governance? A genuine dialogue between all stakeholders to evolve a workable solution would be the best way.

Where does a grouping like BRICS fit into this discourse? To begin with, it has to be recognised that the shift in the global economic power balance has been largely due to the performance of the BRICS countries. The economic heft of BRICS puts them in a position to venture into global governance issues. 
This is not, however, a simple "West vs the rest" notion. Over the past decade, the discourse surrounding the BRICS has been shifted away from such simplistic and confrontational moorings to a more nuanced and inclusive argument for a forward- looking approach benefitting everyone (Stuenkel, 2011). It is common knowledge that BRICS is not interested in a complete overthrow of the existing order. After all, the five countries benefitted in varying ways from some aspects of the order, particularly the great expansion of world trade.

Seen in the context of the succession of global orders, the purpose of BRICS is twofold: to engender an alternative set (or alternative sets) of architectures for global governance, and to begin the conversation that will permit a peaceful and orderly transition from one set of values, norms and rules to another. In other words, it is BRICS that is best placed to manage the "global re-order" - one that will have to reconcile the existing institutions of multilateralism with a new multipolarity for which they have not been designed.

BRICS is in a unique position to address Global Governance issues for many reasons. Firstly, the members come from four different continents and bring their respective perspectives. Secondly, they have the characteristics of both industrialised and developing countries. Many of their problems are similar to those in other developing countries. This helps them to understand the state of play better.

It is true that BRICS has never claimed leadership of the developing world. However, they have an active out-reach program and many initiatives under South-South Cooperation. BRICS therefore has a responsibility to bring forth to the global high tables the concerns and aspirations of the emerging and developing countries.

This does not mean or require a uniformity of approach from the BRICS to the open questions of global importance. Indeed, forcing such a uniformity would be in sharp contrast to the nature of a new global order that could reconcile multipolarity with multilateralism. The BRICS countries represent - sometimes within their own geographies - multiple different sets of norms, regimes of governance, and approaches to solution-finding. BRICS is, therefore, not a single "competitor" but the engine by which a multiplicity of regimes can be presented to the world as an alternative to the one that is clearly outstaying its welcome.

As has been argued by Abhijnan Rej and Samir Saran, ${ }^{3}$ the contribution of BRICS as a complex of overlapping regimes and solutions thus takes three forms. First, it prioritises and promotes developmental goals -where "development" is specific to and dependent on the circumstances of each developing country.

3. REJ, Abhijnan; SARAN, Samir. Thinking BRICS: a conceptual inquiry into emerging powers plurilateralism. New Delhi: ORF, forthcoming. 
Second, it seeks to redress structural unfairness in existing global and political institutions - thereby creating the momentum towards a newer form of global order that is commensurate with the world's changed economy. And third, it provides mutual support, solidarity and assistance in an international system undergoing rapid and confusing transformation.

Thus BRICS' moves in the sphere of political and economic governance must be seen in the context of these three motive forces. The central aspect of the BRICS countries' engagements with each other as well as with the outside world must be an attempt to meet these three needs and thereby create the space for multipolar power by reforming and supplementing the existing power.

\section{POLITICAL GLOBALISATION AND A MODIFIED MULTIPOLAR MULTILATERALISM}

One fundamental element of international relations is that, ultimately, all international issues are political in nature and all decisions are political decisions. This is so because the world consists of sovereign states. Despite noble arguments about universalisation, the reality is that Westphalian states are here to stay for the foreseeable future.

A large part of the credit for the growth in the global economy and reduction of poverty in many countries, particularly in India, China and Brazil, should go to the process of globalisation started in the early 1990s. It led to freer movement of goods, services, investments, technologies, ideas and, to some extent, people across the world. A major outcome was the development of the outsourcing model benefitting the multi-nationals and the developing countries. For the former, the production costs came down drastically and for the latter, employment opportunities increased significantly.

Thirty years later, has globalisation come full circle? Certainly, in many areas there is serious political pushback against the very notion of globalisation. Some in the developed world seems to think that under the process of outsourcing, they were short-changed even though their multi-national companies benefited greatly. They conveniently attributed the increase in unemployment levels to globalisation, which has led to populist and nationalistic narratives. The biggest casualty is the concept of inclusivity. If these trends continue, the world will become fragmented again, by trading blocs, non-tariff and tariff walls, and a balkanisation of the internet - causing great damage to the global economy.

It is not as if the emerging and developing countries had a free ride in globalisation. While developing economies were promised differential treatment in the global trade rules, in practice the centres of global capital had considerable bargaining power when it came to how those rules were implemented locally.

Yet many developing countries, particularly BRICS, adapted quickly to the new game. There was an impressive growth in their economies and improvement 
in their poverty reduction efforts. However, they also had to deal with related problems like unequal growth, increasing gap between the rich and the poor, urbanisation and environmental degradation, and climate change - all without a commensurate transfer of resources to their governments.

Nonetheless, the overall result of thirty years of globalisation has been positive for both the developed and the developing world. BRICS has a special responsibility to restore the momentum in globalisation. The five have repeatedly stressed on this theme in all forums, individually and collectively.

Multilateralism is the bedrock on which a fair, equitable and sustainable world order can be built. Meaningful participation by all is the only way to achieve acceptable results. A fair and equitable world order is not good enough unless it also is clearly seen and agreed to be fair and equitable. The recent emphasis on sovereign power has, however, led to an effort in various quarters to undermine and dilute multilateralism. This is a matter of serious concern for all who wish to see stability in international relations in an age of globalisation.

One unifying aspect of the BRICS countries' approach to multilateralism is a firm respect for the rights of sovereign states, which were sometimes given short shrift by both the post-War and the post-Soviet order. The rights of sovereign states and the nations that they empower to determine forms of development within their boundaries, as well as to shape the currents of globalisation and international co-operation insofar as they pertain to local issues, has always been considered paramount by the BRICS countries.

In some sense, this shared sentiment is now reflected by developments in the world beyond BRICS, including in the developed world. In fact, recent trends have shown that nationalistic sentiments are on the rise and states are taking harder positions on the question of sovereignty. Yet the problem of multilateralism remains: how to build a consensus in such a situation to formulate common values, norms and rules is the major challenge of the day.

The term "reformed multilateralism" has also a contextual significance. Ten years ago, BRICS made their intent clear on reforming the existing multilateral structures because of their deficiencies. Today, due to the trend of a dilution in the multilateral spirit, many countries, particularly in Europe, want to restore the old systems to their previous health. While this impulse may be partially benign, it is not good enough from the perspective of the BRICS countries and of the developing world more generally. A new global reorder must reflect new global realities, and not those of the past.

BRICS has to be in the forefront to thwart such attempts. To their credit, they have been raising this concern individually and collectively in all forums, 
the most recent of which was the G-20 Summit in Buenos Aires. BRICS would have to bring other like-minded countries both from the developed and from the developing world on the same page. The world cannot afford to lose the gains of multilateralism over the past seven decades.

Having said that, the question arises whether multilateralism of today is ideal or whether it needs modifications. Despite the fact that most international fora (excluding the Bretton Woods type Institutions), act on a one-country-one vote principle, in reality, they are dominated by a few powerful countries. Of course, global geo-politics is an important factor. Nonetheless, how can the influence of this factor be reduced to the minimum possible?

The Indian Prime Minister, Narendra Modi, in his address at the $10^{\text {th }}$ BRICS Summit in Johannesburg talked of the need for a "reformed multilateralism" (Pande, 2018). By this, he meant a new approach to multilateralism with corrections to the existing anomalies. It would be a genuine multilateralism without a few dominating the forums. It would also be comprehensive with inter-connections between the various narratives of multilateralism in the different forum. In this, if the existing structures are an impediment to much-needed reforms, there should be no hesitation in reforming, extending or replacing those structures. The following sections discuss each topic and institution related to multilateralism, and what are the efforts BRICS are posing to face them.

\subsection{United Nations Organisation}

In today's world, the single most important global political organisation is the UN. It handles practically every global issue from Peace and Security to Development problems. The global community can take legitimate pride in what this organisation has achieved in the last seventy odd years. The Specialised Agencies of the UN have undertaken commendable work to benefit millions of people around the globe.

Yet, the time has come to assess the effectiveness of two of the most critical organs of the UN namely the General Assembly (GA) and the Security Council (UNSC). They may have had a logic and worked well in the post Second World War scenario. However, the world has changed drastically, particularly in the last thirty years. Are the GA and the UNSC adequate to handle twenty-first century's reality and problems?

As for the GA, there is a near-universal feeling that it should be more powerful with more responsibilities. Making the decisions of the GA binding on the UNSC may be going too far; nonetheless, there is need for a more equitable balance in the powers of the two organs. This has become particularly strongly felt in the unipolar age that followed the collapse of the Soviet Union in the 1990s. 
The composition of the UNSC has definitely become outdated. No doubt, it had a certain logic in the 1940s, but in a very different world of today with many emerging countries with powerful economies and rising regional and global ambitions, it is surely an anachronism. There is no question that it has to be made more inclusive with a greater role for the emerging powers. The process of expansion of the UNSC has been going on since the early 1990s with no visible progress. It is a historical fact that countries, like people in privileged positions, rarely allow dilution of their status. However, if there is indefinite postponement in the expansion process, the UNSC could lose its credibility in the long term.

What of the argument that, for global bodies to be effective, they have to be small? The problem here is that effectiveness without legitimacy is precisely the notion that the BRICS collective has been formulated to combat. Further, can long-term effectiveness really be possible in the absence of legitimacy, which is an essential pillar of support for any institution? Even a die-hard advocate of realpolitik as Kissinger (2014) gives equal importance to power and legitimacy in global institutions. In his book World Order, he argues that power without legitimacy will lead eventually to the unravelling of the organisation and legitimacy without power will make it ineffective. Ideally, as Langenhove (2011) says, "the key issue in relation to any institutional reform aimed at reinforcing multilateralism is how to create a balance of power among UN members and a balance of responsibilities and representation for the people of our planet".

So far, the BRICS have not had a united stand on the question of UNSC expansion. Two of the five BRICS partners (Russia and China) are Permanent Members and the other three (India, Brazil and South Africa) have legitimate aspirations. Critics of BRICS have commented upon the lack of a consensus on the issue as a negative factor for the group. BRICS has to arrive at a common position on this question very soon.

\subsection{Internet governance, cyber security and disruptive technologies}

Internet governance, cyber security and disruptive technologies are new areas where the developed West has still not set the final rules. What exists at this point are, at best, interim arrangements. That is where BRICS has an opportunity to take initiatives, and ensure that they would be among the rule makers and not rule takers as in the past.

All the five are big consumers of the internet. Therefore, it is only logical that they must have a say in its governance, alongside other major stakeholders and consumers. Everybody agrees on the need for a fine balance between encouraging creativity and curbing exploitation. It has to be a market plus approach. The efforts so far have not led to a final model of internet governance based on a multi-stakeholder principle. BRICS has to be in the forefront in these discussions 
to ensure their leadership role. However, any change must also take into account the basic requirement for a free and open internet - namely, that governments and corporations are also held to account and follow norms that render them responsible to each other and particularly to end-consumers. This is another location in which a new multilateralism needs to evolve.

Cyber security has assumed great importance in the last decade thanks to the exponential growth of digital platforms globally. The transnational nature of cyberspace and absence of geographical constraints raises many issues. Cyber security covers a wide terrain. Nye (2010) identifies four distinct types of threat: i) cyber war, which is the unauthorised invasion by a government into the systems and networks of another country with the aim of disrupting their systems; ii) cyber espionage, which is the invasion of systems to steal sensitive information, this could be by governments, non-state actors or the corporate sector; iii) cybercrime, which affects ordinary internet users and includes theft of data, illegal transfer of funds from bank accounts of others, and so on; and iv) cyber terrorism, which is mostly conducted by non-state actors, if sometimes with covert state backing, and involves spreading terrorist ideology, recruiting terrorists and hacking into government systems to paralyse them.

On all these four threats, the international community is still struggling to find viable solutions. Can the BRICS countries put their heads together and come up with their perspectives? It is still a virgin field as far as governance is concerned.

One of the biggest modern challenges is the rise of disruptive technologies. Artificial Intelligence, big data and block chains will very soon become household names. As they spread across the globe, there will be need for regulation and governance of these areas. The time to think about them is now. BRICS would do well to put together their best experts on the subjects and come out with models of governance before the West put new rules in place.

\subsection{Energy security}

For many emerging and developing economies, the cost of energy is a key determinant of economic prosperity. Their growth and macro-economic stability are dependent on the state of the commodity cycle generally, and more specifically on the price of crude oil. Energy security thus is a major component of their individual development agendas, and as such is also a part of the BRICS' agendas.

A United States government agency estimates that by 2025 demand from the BRICS countries will be 38 per cent of the world's overall primary energy demand - although the Russian federation, for one, is now also the world's largest exporter of natural gas. Even so, the International Energy Agency (IEA) estimates that it is developing countries that will represent the greatest proportion 
of increases in energy demand going forward to 2040. India itself will demand over 1,000 Mtoe more, and China 790 Mtoe - while Europe, for example, will see a decrease in primary energy demand of 200 Mtoe.

The current governance paradigm for global energy security relies on the very IEA that has made this prediction to speak for oil and gas consumers. Unfortunately, the IEA emerged from an older global order, in response to one of the earlier efforts to disrupt it. The formation of the oil exporting cartel OPEC in the 1970s precipitated first the oil price crisis and thus stagflation in the developed world - and then, as an institutional response, the creation of the IEA. Because of this origin, the IEA is strictly limited in terms of its scope. For example, to be a member of the IEA, a country has to qualify for membership of the OECD group of richer nations. Thus, India and China, the two great drivers of future energy demand, are merely observers at the IEA.

As with the International Monetary Fund (IMF), so with the IEA: the institutional architecture of multilateralism that emerged from a bipolar world and was strengthened in a unipolar one has led to measurably worse outcomes for the developing world. The Indian government, including current Union energy minister Dharmendra Pradhan, have made a so-called "Asian premium" the central plank of their energy diplomacy (Sharma, 2018). This is the argument that, throughout the 1990s, the cost of a barrel of oil shipped to Asian countries was between US\$ 1 and US\$ 1.50 higher than that shipped to Europe or North America - according to Chiu and Pleven (2010) in The Wall Street Journal, it was US\$1.20 higher since 1988. A director at an Indian state-owned petroleum company estimated that OPEC's prices for India were between US\$ 2 and US\$ 3 higher a barrel.

The IEA has, since the crisis of 2008, recognised that its own legitimacy as a representative of oil consumers is under threat as a consequence of its failure to expand its membership. It has, therefore, focused on conversations with three members of the BRICS collective - India, Russia and China - "in the hope of developing strong multilateralised ties even in the absence of formal membership" (Florine, 2011, p. 45).

Here, again, there is a concrete role for the BRICS to play individually and collectively. The July 2018 BRICS declaration included the following line:

we reaffirm that the diversification of energy supply sources, including renewable and low carbon energy sources, investments in energy and energy infrastructure, energy industry and market development and intra-BRICS collaboration for access to primary energy sources will continue to underpin our energy security (Brasil, 2018).

Three of these four goals are best served by reform and renovation of an existing institution - the IEA. Here, again, is a requirement for the institutions of multilateralism to reform themselves to serve the needs of a multipolar world, as expressed in the BRICS leaders' declaration quoted above. 


\subsection{Economic governance}

The global financial crisis of 2008 was a watershed for the global economic order. Three broad trends were noted in response.

First, it became clear that laissez-faire approaches to the global economy were intellectually and practically insupportable. To the extent that the existing guarantors and centres of world finance were responsible for the crash, they lost legitimacy as the determiners of growth, economic, financial and regulatory models, which opened up space for alternative regimes, such as the complex represented by the BRICS grouping.

Second, the errors of the private sector may have caused the crash, but the solutions had to be provided by sovereign governments. In some cases, this required the expansion of public debt; in others, it required prolonged periods of austerity. In both cases, however, it became obvious that some form of restitution would be needed, as well as a correction of the imbalance in power and capability that had grown up between the sovereign and capital. Space that had been ceded to apparently uncontrollable and trans-national forces like global capital would have to be reclaimed by the sovereign state. This meant new and expanded architectures of economic global governance - which took into account, in particular, the demands and expectations of emerging economies and the developing world who also did their part, and in fact in some ways took the lead, in cleaning up the mess.

Third, the crisis year of 2008 made clear that existing institutions of global governance were incapable of responding or preventing trans-national threats to the global economy. Rather than any previously powerful institution, the world responded to the crisis primarily through the auspices of the G-20 grouping, in which emerging economies also had a strong voice. While the G-20 continues to be a potent forum for global governance, it does not solve the problem of multilateralism as described earlier in this paper nor is it an institution as such.

The reform, renovation and extension of the institutions of global economic governance that the BRICS countries seek must be seen as realistic acknowledgements of these three post-crisis learnings: the legitimacy gap for existing norms, the return of sovereign power, and the ineffectiveness of legacy institutions.

The post-crisis economy is inherently and organically multi-polar, and multilateralism must modify itself in response. The institutional interventions that are in keeping with the BRICS projects are thus of two sorts: renovation and reform of existing institutions of global governance, and their extension or paralleling.

The IMF and the World Bank are the two great Bretton Woods institutions that essentially oversaw, respectively, global economic stability and development. 
It would be unfair to say that these multilateral agencies failed completely to change with the times. They have broadened their staffing, extended their scope and altered their dogma several times in keeping with the rise of emerging economies. Yet, reform of the leadership of these institutions has long been delayed.

The IMF provides an illustration of this phenomenon, as well as of the dangers of such a delay. The IMF's $15^{\text {th }}$ General Review of Quotas is supposed to be concluded by the 2019 bank-fund meetings. This redistribution of voting rights within the IMF would strengthen the hands of developing countries within the IMF, thereby ensuring a more effective and equitable response by the agency.

How important is this? In some sense, the post-crisis actions of the IMF have made clear exactly how the domination of the institution by the West warps its functioning. In the aftermath of the crisis, the IMF found itself operating within its "home" geography of Europe - the fund has traditionally been run by a European, just as the bank is run by an American. Portugal, Ireland, Cyprus and Greece among others needed assistance from the IMF. Yet the degree of assistance that, for example, Greece received seemed far in excess of how much the IMF has committed to other programmes in the developing world. IMF lending to a particular country is usually linked to the membership contribution of that country. The general limit of such lending is 600 percent. But Greece received a record bailout of 3200 per cent of its membership contribution - far beyond anything that a developing country could imagine receiving.

This was a clear product of the European nature of a supposedly global and multilateral institution. And the response to the IMF's usual insistence on contraction of spending and reduction of public debt during a structural adjustment programme is also worth considering. Such "austerity" has always and everywhere been politically unpopular. However, not until the protests against IMF-driven austerity happened in the home-ground of the IMF did the fund seek to revisit its dogma about structural transformation.

Whether this revisiting was correct or incorrect is not the issue at stake here. What is clear instead is that the lack of representation for developing countries and emerging economies has had a clear effect - the IMF lends less and is less likely to question itself when operating in developing countries than in its "home" geography of Europe. This has led to questions correctly being asked about the overall legitimacy of the fund.

In their declaration of 2018, the leaders of the BRICS countries specified that the $15^{\text {th }}$ General Review must include an increase in the voting rights of developing countries, particularly those in Africa. This is an important goal, and one that furthers the notion that the BRICS grouping serves as a legitimate representative of emerging and developing countries. Yet the biggest reform of the IMF, surely, is to make its leadership contest open to all, rather than restricted to a European nominee. 
About trade norms and institutions, it is fair to say that many of the BRICS countries have emerged over the past years as vocal defenders of the need to preserve the open and inclusive spirit of globalisation that has animated the past several decades. This has come at a backdrop of clear dissatisfaction with the global trading order from many countries, including powerful developed economies like the United States.

In September of 2018, the chief trade-related officials for the European Union, the United States and Japan issued a joint statement from New York that underlined the manner in which they sought to remake the World Trade Organization in particular. Reading between their lines, one of their crucial demands was that the differentiated treatment due to developing countries under the current trade architecture should be phased out over time.

The developing world and the BRICS countries in particular are thus faced with a peculiar situation - the one global organisation that has been largely helpful in their rise to economic prominence is now under threat. But the BRICS approach to this has not been straightforward - and nor could it be, given the multitude of interests the BRICS countries represent.

However, there are certain important questions that the BRICS will have to grapple with in the context of WTO reform - questions that impinge even upon their claim to represent the developing world. The greatest of these questions is whether the notion of a "developing country" is under threat given the economic growth of the BRICS and others in recent years. The answer to this question must come from the BRICS countries themselves and cannot be left to the developed world to deliver. The best way to solve the question of trade and development would be, in fact, to breathe life into the only genuinely multilateral effort to promote trade for development: the Doha Round.

When it comes to the arteries of the world economy, namely global finance, there have been ongoing efforts to congest or block off those arteries by the use of personal or national sanctions regimes. For the BRICS nations, this is a major threat to their internal and external trade finance and thus to the flow of goods and services. Here, again, it is up to the BRICS to ensure that the institutions of global finance (like the SWIFT system of inter-bank transfers) correctly represent the changed circumstances of a multi-polar world.

The experience of developing countries worldwide, and that of many of the BRICS economies, is one of capital constraints. Even if abundant capital is technically available, it may not be of the quality or tenure that is needed from the point of view of national development strategies. In particular, banks in the core economies of global finance have ceased lending across borders for long-term projects such as in infrastructure (Sharma, 2018a). 
The consequence of this shortage for development strategies in emerging economies and developing countries is severe. In many if not most cases, taking full advantage of globalisation, in particular of the growth in global trade, requires the upgrading of obsolete and deficient infrastructure, or the creation of absent infrastructure. Such projects require a corresponding amount of project finance. Given that the private sector is not stepping up to meet this deficit in project finance, governments in developing countries and of emerging economies are forced between various unpalatable choices: they might raise taxes and pay for the infrastructure themselves; they might raise debt and pay in that manner; they may divert funds from other important needs such as health or education; or they may rely on specialised development finance.

Multilateral development banks and agencies, such as the World Bank, were designed to fulfil precisely this need. However, the World Bank's governance has been as unreformed as that of the IMF discussed above. As a consequence, the bank does not fully take into account the needs and requirements of developing economies when formulating its policies.

As with the IMF and the IEA, there are direct and visible consequences of this lack of representation. For example, the bank has now taken a decision to not lend further to fossil fuel-related projects. While the desire to meet the targets set by the Paris Agreement on Climate Change is laudable, this decision is nevertheless not in keeping with the spirit of the Paris Agreement, which privileged nationally determined strategies that combined development constraints and emissions targets. Once again, a multilateral organisation failed to recognise the realities of a multi-polar world, in which multiple development paths must be recognised as valid.

It is in this context of failure that the decision to set up alternative institutions, such as the New Development Bank, must be seen. The challenger agencies have a less rigid and dogmatic agenda than the legacy multilateral development banks - a product not just of their design, but of the underlying BRICS vision for alternative norms that privilege sovereign choices. The central question with new development agencies will be one of effectiveness. Can they mobilise sufficient capital in hard-to-reach geographies without falling into the trap of dogmatism and central direction that has bedevilled the legacy MDBs (Sharma, 2018b)? The build-out of infrastructure in a new global re-order cannot by any means be dominated by the agenda of any single player, or group of players - disrupting such a situation is precisely why the BRICS collective continues to retain relevance.

Finally, one major economic field in which the architects of the dissipating post-war and post-Soviet global order continues to exert considerable and disproportionate power is the setting of global norms and the calculation of credit ratings. 
The latter, the process of quantifying and rating economic risk, is a major component of why long-term finance from the private sector has become hard to come by in emerging economies. This is why the BRICS leaders have frequently referred to the need for creating alternative credit ratings agencies. The 2017 BRICS declaration included the following line: "we commend the progress in concluding the Memoranda of Understanding among national development banks of BRICS countries $(. .$.$) on interbank cooperation in relation to credit rating". { }^{4}$ Unfortunately, progress on this in 2018 has been insufficient, and thus it found no space in the leaders' declaration the following year. This will need to be corrected.

Finally, BRICS will have to take the lead in the formulation of cross-border norms and standards that facilitate global trade. "Behind the border" requirements have become a feature of major regional trade agreements. Working out such norms in the context of a trade negotiation leaves open the possibility that they will be held hostage to other aspects of the trade agenda, even pertaining to intra-BRICS trade. The need therefore is to create an alternative, independent location where such norms could be discussed and formulated. This would be fully in keeping with the BRICS' basic desire to create multilateralism within a multipolar world.

\section{CONCLUSION}

The world is entering a process of re-ordering. The old global order, created by the victors of the Second World War and the Cold War, is being superseded. The new global reorder will have to reflect the shifting economic centre of gravity of the world, as well as the multiple centres of power that have been created as a consequence of economic growth.

The challenge for the BRICS countries, and for the intellectual complexes that define their national and international strategies, will be to manage the transition to a new global reorder without chaos or conflict. This transition will require the creation of institutions that reflect the BRICS ethos of sovereign choice, alongside the norms of multilateralism - thus multilateralism with multipolarity. In some cases, this can be done by the reform and renovation of institutions, such as the IMF. In other cases, it will require the extension of existing institutions or the creation of equally or more effective alternatives, such as new development finance agencies. In all such cases, the BRICS countries have a responsibility to serve as the voice not just of their own populations but also of the entire emerging world.

4. Available at: <https://bit.ly/3ev5ve8>. 


\section{REFERENCES}

ALTINAY, Hakan. The state of global governance: an audit. Washington: Brookings, 2010. Available at: <https://www.brookings.edu/articles/the-state-ofglobal-governance-an-audit/>.

BRASIL. Ministério das Relações Exteriores. Johannesburg declaration. [s.l.]: BRICS, 2018. Available at: <http://www.itamaraty.gov.br/pt-BR/notas-aimprensa/19236-x-cupula-dos-bricsdeclaracao-de-joanesburgo-27-de-julho-de2018-ingles>.

BREMMER, Ian. Judy asks: is the post-WWII global order finally breaking down? [s.l.]: Carnegie Europe, 2015. Available at: <https://carnegieeurope.eu/ strategiceurope/59994>.

CHIU, Carolyn; PLEVEN, Liam. Economic clout earns Asia an oil discount. The Wall Street Journal, 25 May 2010.

FLORINE, Ann. The International Energy Agency in global energy governance. Global Policy, v. 2, n. s1, p. 40-50, 2011.

KISSINGER, Henry. World order. [s.l.]: Penguin Press, 2014. p. 433.

LANGENHOVE, Luke van. Multilateralism 2.0: the transformation of international relations. Tokyo: UNU, 2011.

NYE, Joseph. Cyberpower. Cambridge, Massachusetts: Belfer Center for Science and International Affairs, 2010.

PANDE, Hemant. PM Modi to address the 10th BRICS summit in Johannesburg today. Kalinga TV News Network, 26 July 2018. Available at: <https://kalingatv. $\mathrm{com} /$ state/pm-modi-to-address-the-10th-brics-summit-in-johannesburg-today/>.

SHARMA, Kiran. India leads regional charge to end OPEC's Asian premium. Nikkei Asian Review, 25 Oct. 2018.

SHARMA, Mihir. The crisis of global finance. [s.l.]: ORF, 2018a.

An incomplete agenda: multilateral development banks and the green infrastructure gap. [s.l.]: ORF, 2018b.

STUENKEL, Oliver. West and the rest. The Times of India, 23 Aug. 2011. Available at: <https://timesofindia.indiatimes.com/edit-page/West-and-the-rest/ articleshow/9700177.cms>.

TRENIN, Dmitri. Judy asks: is the post-WWII global order finally breaking down? [s.l.]: Carnegie Europe, 2015. Available at: <https://carnegieeurope.eu/ strategiceurope/59994>. 